\title{
TIETOSUOJALAKI TULI VOIMAAN VUODEN ALUSSA
}

\author{
Pekka Heikkinen
}

E duskunta hyväksyi 20 I 8 loppuvuodesta kansallisen tietosuojalain. Laki tuli voimaan vuodenvaihteessa ja se korvasi aiemman henkilötietolain.

Uusi tietosuojalaki täydentää jo aiemmin voimaan tullutta EU:n yleistä tietosuoja-asetusta. Molempia säädöksiä tulee soveltaa rinnakkain. Muun muassa tästä syystä oikeusministeriön lakiluonnosta kritisoitiin valmistelun kuluessa ankarasti; lakia pidettiin vaikealukuisena ja sen soveltamista hankalana.

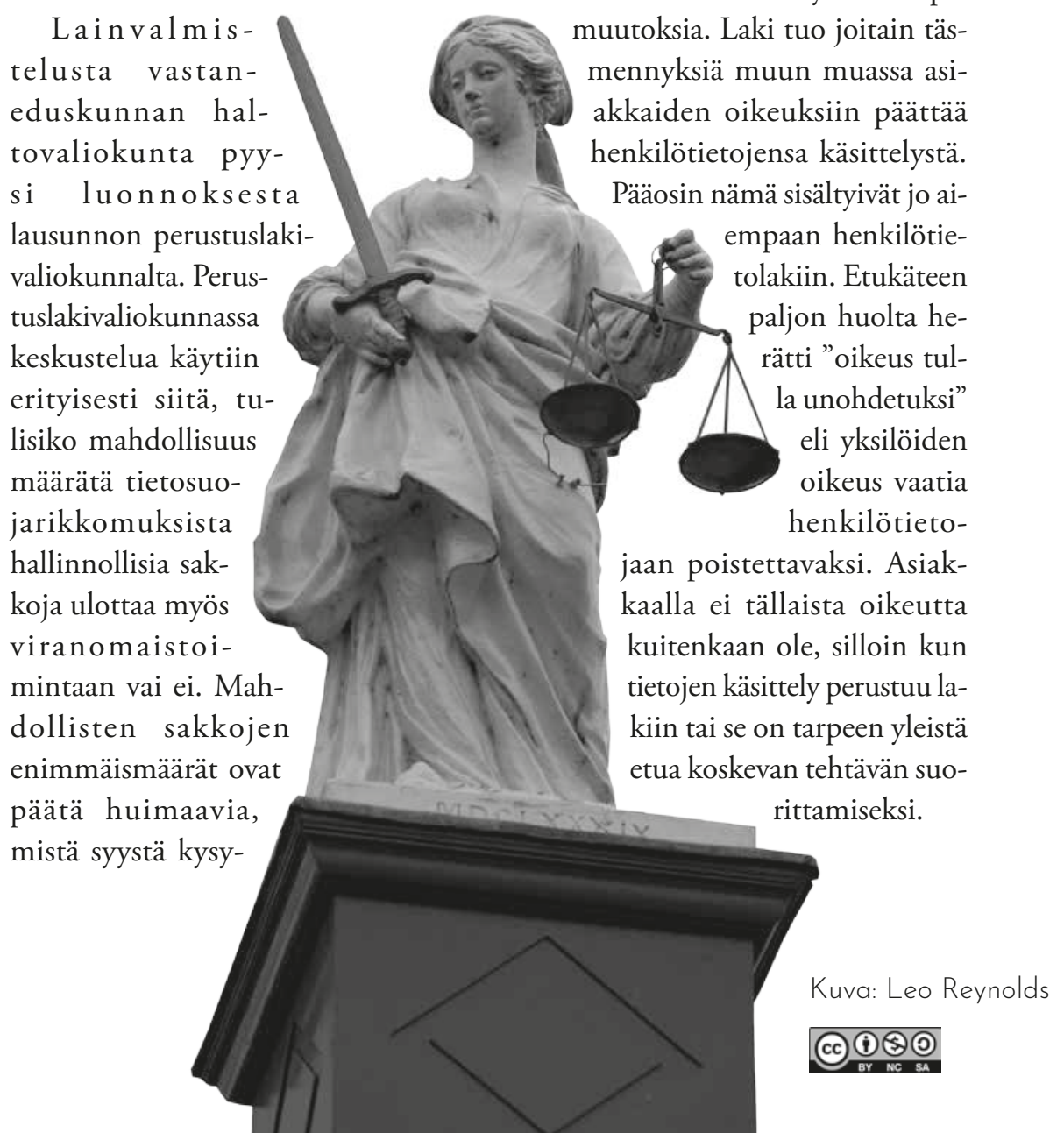

mys herätti ennalta pelkoja myös kirjastoissa. Perustuslakivaliokunta päätyi kuitenkin siihen, että julkishallinnossa ja viranomaistoiminnassa vastuut on jo nykyisin märitelty niin selkeästi, ettei lisäsanktioille ole tarvetta.

EU-asetus jätti kansallisesti linjattavaksi sen, minkä ikäisen lapsen henkilötietojen käsittely on sallittua ilman holhoojien suostumusta. Suomi päätyi soveltamaan asetuksen sallimaa vähimmäisikää, joka on I 3-vuotta.

Täysistuntokäsittelyssä lakiehdotukseen ei enää tehty suurempia muutoksia. Laki tuo joitain täsmennyksiä muun muassa asiakkaiden oikeuksiin päättää henkilötietojensa käsittelystä. lakiin. Etukäteen paljon huolta heeli yksilöiden oikeus vaatia henkilötietojaan poistettavaksi. Asiakkaalla ei tällaista oikeutta kuitenkaan ole, silloin kun tietojen käsittely perustuu lakiin tai se on tarpeen yleistä etua koskevan tehtävän suorittamiseksi. 
irjastojen, arkistojen ja museoiden yhteinen juridiikkaryhmä pyrki lausunnoillaan vaikuttamaan lainvalmisteluun siten, että lakiin kirjattaisiin selkeästi kirjastojen mahdollisuus saattaa henkilötietoja sisältäviä aineistoja myös yleisön saataville. Nyt mainintaa ei ole itse laissa, ainoastaan siihen liittyvässä hallituksen esityksessä. Hallintovaliokunta kuitenkin totesi, ettei tällaista säännöstä ollut aiemmassa henkilötietolaissakaan. Oikeustilanne ei siis muuttuisi aiemmasta. KAM-sektori on myös alueena epäyhtenäinen ja kulttuuriperintöaineisto käsitteenä täsmentymätön. Valiokunta kuitenkin totesi, että jos asia tulevaisuudessa muodostuu ongelmaksi, asiaa tulee selvittää ja lakia tarvittaessa muuttaa.
Tietosuojalaki sisältää kuitenkin säännöksen, jonka nojalla kulttuuriperintöaineistoja ja niiden kuvailutietoja voidaan käsitellä, jos tämä on tarpeen ja oikeasuhtaista tavoiteltuun yleisen edun mukaiseen tavoitteeseen nähden. Se, mikä on tarpeen ja oikeasuhtaista jää kirjastojen itsensä linjattavaksi. Tässäkin suhteessa Eu:n tietosuoja-asetus jättää toimijoille tavanomaista enemmän liikkumavaraa. Soveltamisen osalta lisätukea voidaan hakea myös muotoilemalla alakohtaisia käytännesääntöjä, jotka voidaan hyväksyttää tietosuojavaltuutetulla. Tällaisten käytännesääntöjen muotoilu on jo käynnissä niin yliopistoissa kuin kirjasto-, arkisto- ja museoalan juridiikkaryhmässä.

\author{
Tietoa kirjoittajasta \\ Pekka Heikrinen \\ Lakimies, Kansalliskirjasto \\ pekka.heikkinen@helsinki.fi
}

